\title{
CONTENTS ÍNDICE DE MATERIAS
}

Foreword: The Vantage Point of Memory

Prólogo: El mirador de la memoria

Rigoberta Menchú Tum

Introduction

Presentación

Oscar Iván Maldonado

Angels, Conquests, and Memory

Ángeles, conquistas y memoria

W. George Lovell

PORTFOLIO

Daniel Hernández-Salazar, Photojournalist

Daniel Hernández-Salazar, fotoperiodista

Icon of Memory

Icono para la memoria

Miguel Flores Castellanos
Daniel Hernández-Salazar, Postmodern Humanist

Daniel Hernández-Salazar, un humanista posmoderno Michael A. Weinstein

\section{PORTFOLIO}

$6 \quad$ Memory of an Angel

13 Memoria de un ángel

Photography, Urban Space, and the Historical

Memory of Atrocity: The Angel Series

Fotografía, espacio urbano y la memoria histórica

de la atrocidad: La serie del ángel

Steven Hoelscher

23

29 Biographies

Biografías 


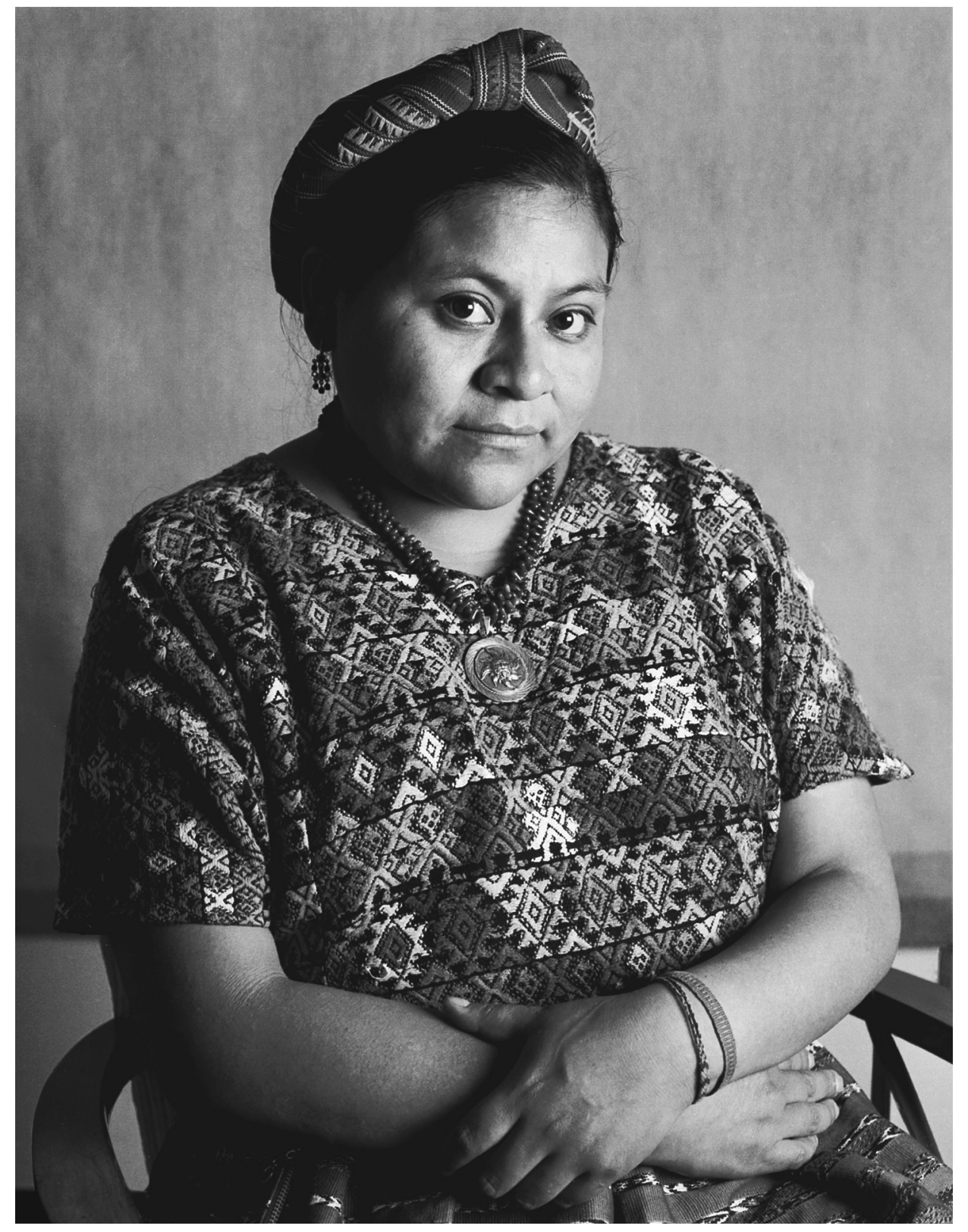

Rigoberta Menchú Tum, I992. 